\title{
A quest for sacred knowledge: Mentorship to partnership
}

Rebecka Black, Elizabeth Garber, Eryn Neff and Manisha Sharma, University of Arizona

\begin{abstract}
Faced with the challenge of developing a mentorship relationship between faculty and graduate students that would result in a partnership, intrepid scholars Becky, Elizabeth, Eryn and Manisha encounter uncertainty, disillusionment and teaching obstacles. Optimism is followed, in their working process, by a search for a meaningful focus for the collaboration that charts new territory and simultaneously captures the interest of each scholar. Beginning with the broad theme of technological tools in teaching, they move to the educational use of video games and settle on the concept of play. Their persistence leads to a change of mission, one that grows out of their mutual work and discussions together, and commitment to their roles in a supportive partnership that involves a 'community of practice' (Wenger et al. 2002). The trust this establishes allows for a questioning of the concept of Sacred Knowledge in Academia during the writing process.
\end{abstract}

\section{Keywords}

mentors

mentees

gaming

play

partnership

mentorship 


\section{Accepting the quest}

A long, long time ago in the Age of Scholars, the spark of Sacred Knowledge of Academia had vanished. Now, found only in epics of brave Academics in ages past, no soul had seen the Sacred Knowledge for aeons. But Academia now required the Sacred Knowledge to be unearthed again, for the lifeforce was waning. Two Sages, Ami and Mary, put forth a call throughout the realm for champions to find the hidden Sacred Knowledge. In the quiet beauty of the desert kingdom of Tucson where pomegranate trees bloomed, Hogwarts Mistress and scholar Elizabeth Garber heard this call. Her burning sense for social justice and research on the role of gender in art and visual culture led her to enlist the intrepid Manisha Sharma, padawan from another land, in this Quest. Elizabeth knew that Manisha's work in gathering knowledge with and about communities and their hybrid identities would be crucial in detecting the Sacred Knowledge, perhaps through new technologies. But they knew they could not journey forth on this Quest alone - The Sages forbade it. It was decreed that only the infusion of new perspectives would make visible again the spark of Sacred Knowledge, and save Academia.

Elizabeth and Manisha, mentors and friends, journeyed through their desert campus, lush with prickly plants and chirping birds in the clerestory of trees, searching for two skilled and spirited mentees to join them on this collaborative Quest. They sought collaborators who would be interested as well as skilled in the topical arena and language of technology. Their Quest was supported by other scholars who saw merit in this vision (Duncum 2015; Jones 2015). 

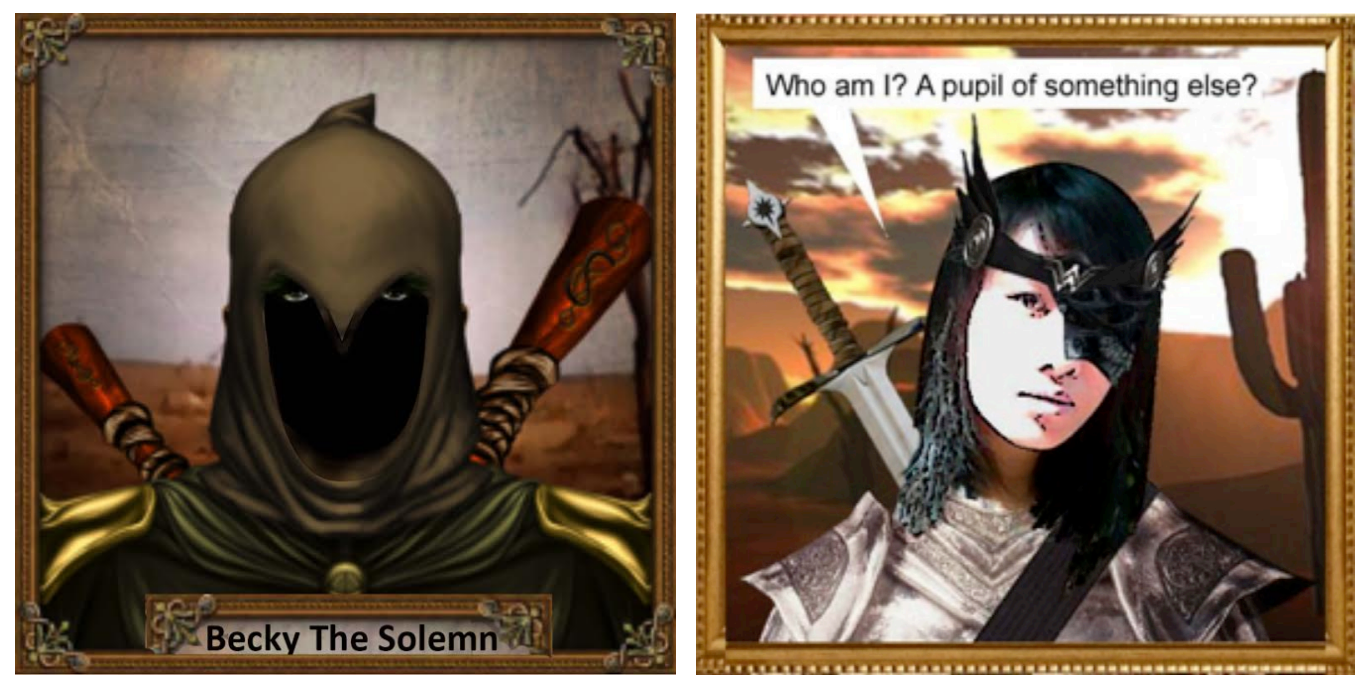

Figure 1: Rebecka Black, 'Becky sets out on The Quest', 2016. Digital image.

Figure 2: Eryn Neff, 'Eryn joins the Quest', 2016. Digital image.

Among the towering Saguaros they found their brave companions. Shrouded in mystery, they were known as The Doctoral Students, Eryn Neff and Rebecka ‘Becky’ Black (please see Figures 1 and 2). Eryn, originating from a land to the East, held the mystical knowledge of new technologies and issues of identity. Her teaching, even of large classes, suggested a stronghold in itself. She was especially clever in working with the power of Games and training youth in using them well. And deep in the mysteries of gender and Marxist Feminism, she clearly presented the visage of a warrior. Becky was a keeper of Histories of Art and was deft in the practices of many guilds, including Museum Education and Problem Solving. She was also, secretly, an elder in the ways of Games and brought its nuances to her work and teaching; this she had in common with Eryn. And so it was that Elizabeth and Manisha had found the missing links needed for The Sage's quest. The Mentors and The Doctoral Students set off to find the Sacred Knowledge and save Academia (please see Figure 3). 


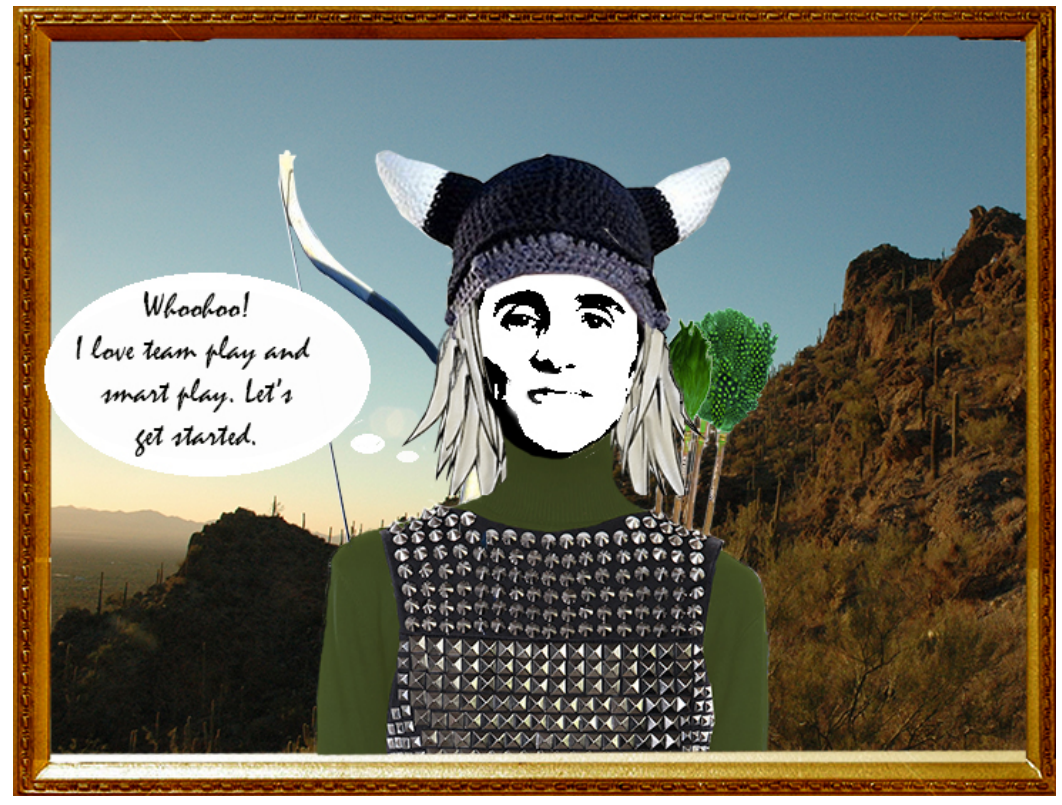

Figure 3: Elizabeth Garber, 'Elizabeth sets out on the collaborative journey', 2016.

Digital image.

\section{Behold the wall of preconceptions!}

As our heroines set out to find the Sacred Knowledge they first had to understand their roles in this Quest. The Faculty were already members of an elite society of knowledge, guiding the fates of future art educators. But The Doctoral Students were only part of a scattered assembly of fledgling scholars in their desert kingdom. Navigating these hierarchical identities, discovering who was to lead and the roles each would play surely was to be decided by the elder Faculty. After all, The Faculty chose The Doctoral Students for this Quest (please see Figure 4). 


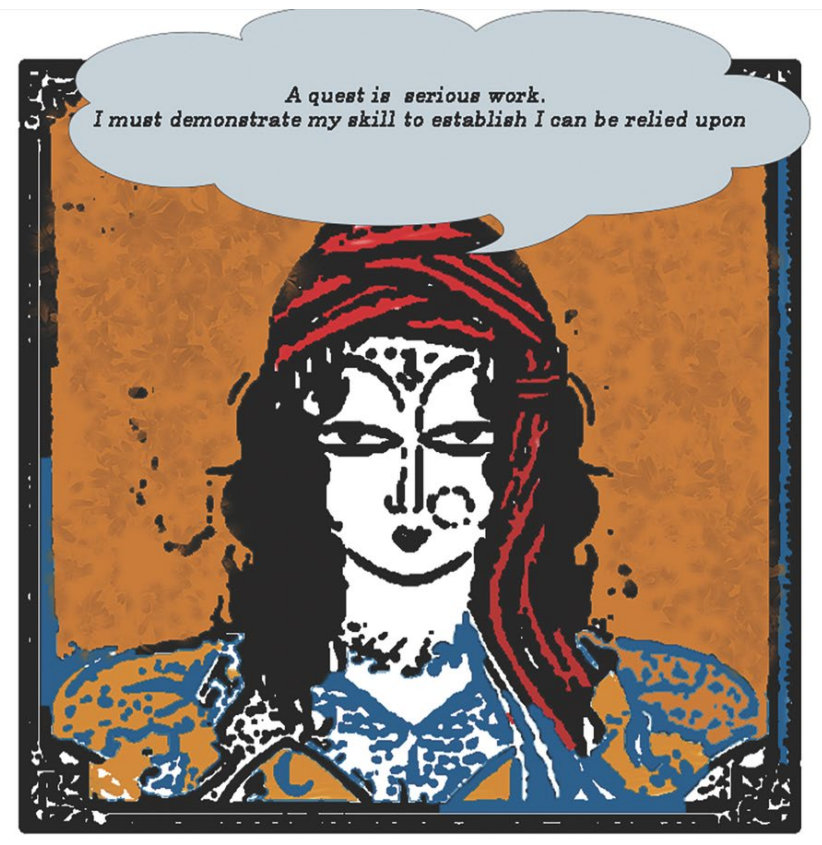

Figure 4: Manisha Sharma, 'Manisha’s uncertain footings', 2016. Digital image.

Becky, thinking of this master/apprentice model, looked to Manisha and Elizabeth for the arcane wisdom thought to be hidden in mentors (Rockquemore 2016). Adopting the role of grateful mentee, she felt ready to absorb and bask in the noble guidance that would skyrocket her academic career from their benevolence (Daloz 1983; Stokes 2003). But she had few expectations of Eryn. Although intrigued by Eryn's skills, Becky expected their collegial but distant relationship to remain unchanged during this Quest. She looked only towards her future career rewards of having been mentored by The Faculty.

Eryn, enveloped in uncertainty, focused on her background of successfully teaching technology and patiently waited for the road to appear. 'I hope I'll do well', she secretly ruminated. This was certainly not the first time she found herself sitting in Elizabeth's office, but in these new circumstances, Eryn imaged herself a Stranger from the East walking into an unfamiliar realm. She was unable to categorize her standing: was she a pupil, or something else? She sat down, aware of the tension and silence hanging in the air, or was it all in her imagination? Elizabeth, armed with magic green quivers and a composite bow, obliviously 
basked in the sun and Saguaros and looked forward to a thornless synergistic partnership (Mullen 2000) wandlessly growing from a few meetings.

\section{The gauntlet of awkward silence}

Through vertiginous winds, scorching heat, menacing mountains and awkward silences in Elizabeth's office, each warrior clung to her thinking that technology and teaching was the path to Sacred Knowledge. Ever inscrutable, Eryn persevered but there remained for her some nerves and uncertainty about her purpose within this group. Elizabeth began to feel unease: had she lured others into a Den of No Return rather than a path to the Sacred Knowledge? Despite the life-changing experience of being mentored and of mentoring others, this Quest, prompted by the vision of distant Sages, was a new path indeed (please see Figure 5). Becky grew impatient. The Sacred Knowledge was lost and so too would be her future career as tenured professor if The Faculty did not intervene and lead this quest. She wanted so much to follow the Sages' advice to 'take action' (Casto et al. 2005: 333) and lead. Nevertheless, she remained silent, not wanting to overstep the boundary she imagined between herself and The Faculty.

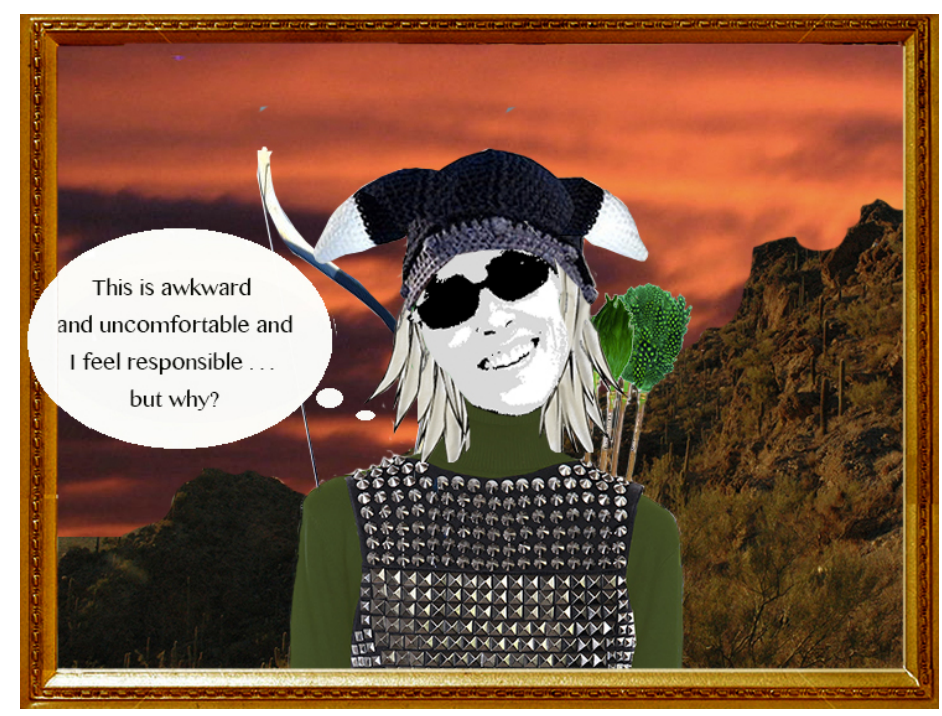

Figure 5: Elizabeth Garber, 'Elizabeth’s unease grows', 2016. Digital image. 
The four persisted in their impalpable partnership, politely internalizing their frustrations. That path became littered with apps and programmes: 3Dtin and Sculpteo.com.

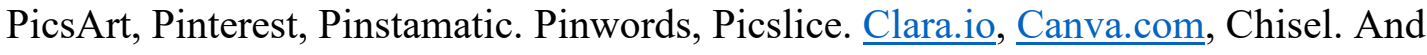
mountains more, all with the hope it could lead them to the path to uncover the Sacred Knowledge (please see Figure 6).

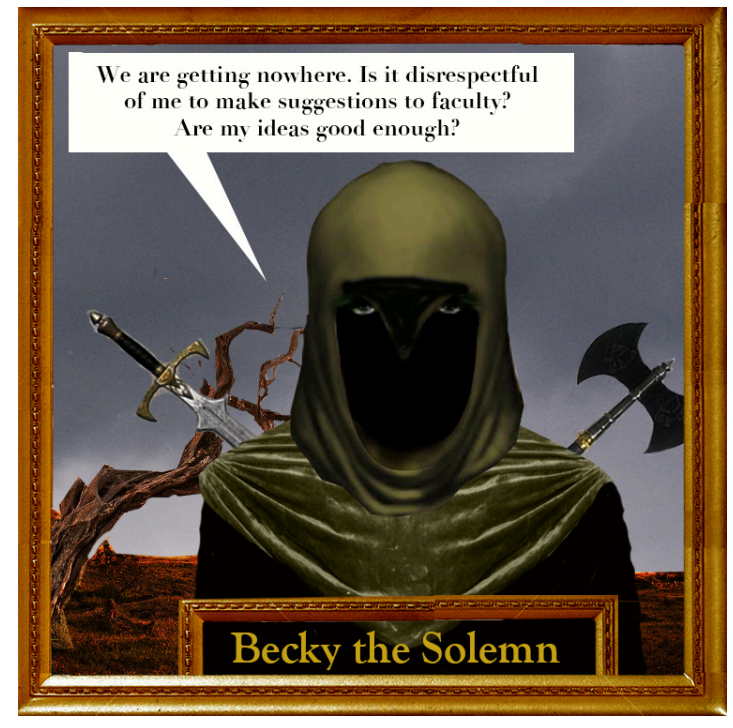

Figure 6: Rebecka Black, 'Becky has an idea', 2016. Digital image.

Thirst for progress and exhaustion from impatience was threatening to halt The Seekers' nascent partnership. The highway towards the Sacred Knowledge, lined with skyward buildings that glittered in the bright sunshine, became littered with failed virtuality. Delirious and blistered from what were becoming stilted discussions, recklessly Becky exclaimed, 'What about video games?'. Despite other Sages' reservations (Hergenrader 2016), she dared think that video games might reveal the True path to uncovering the Sacred Knowledge; she proferred Artsology.com and Molleindustria.com. But would The Seekers agree to this path? Again she feared violating the perceived boundaries of the mentor-mentee relationship. Nonetheless, she was confident in her knowledge that game-based learning was valuable and growing in higher education (Johnson et al. 2015). Eryn embraced the plan! Manisha was enthusiastic, though she had rarely played games, and even more rarely done 
well at them! Elizabeth, having consistently lost every video game ever played with her children, felt the mantle of responsibility lighten. And so the four, reinvigorated, set off on their own gaming task to play games for the summer.

\section{The path or a mirage?}

Scattered across Academia, The Seekers battled through memory challenges in the Paris Street Art and Graffiti Battle games. They waded through the collision course of spheres in the Yoyoi Kusama Dot game on Artsology and they faced down controversial cultural foes in Operation: Pedopriest and Run Jesus Run on the Molleindustria site. It was familiar territory and technology for Becky. But what of her companions?

Elizabeth, camped out under a ramada with a hot wind blowing, scored 4980 on the Keith Haring Pinball game first try. Was she hooked? Only twenty points more to get to the next level! Next try, she failed ... and the next. To armour herself further, she reasoned, 'The designs are Haring ... what's the other value? Maybe students could compare it stylistically to other games? ... Let's try Yoyoi Kusama Dots'. And so she laboured on through Paris Street Art Game, Graffiti Battle Game, Op Art Stack Game and looked for missing artist Russell Vapors on Project M.A.R.V. 'I think I'll go back to the studio'. She wandered off.

Manisha gleefully embarked on an exploration of video games wearing academic and professional development as armour. She had ceased playing games competitively ages ago, disliking how aggressive it made her. Unexpectedly, she now revelled in the irreverent games of Molleindustria.com, the hypnotic quality of the Keith Haring pinball game, and the dreamy quality of the Yoyoi Kusama game. She failed to see how she might introduce these in the classroom so as to capture the attention of the students who were likely to be far more conversant in this landscape than she (please see Figure 7). 


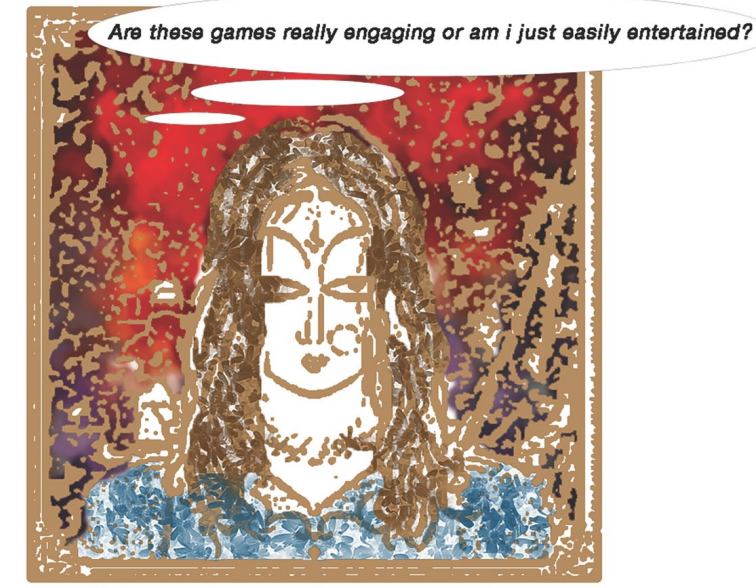

Figure 7: Manisha Sharma, 'Manisha questions the question', 2016. Digital image.

With curiosity and excitement for an adventure, Eryn began playing the games, but her journey did not go far. As she played, something was amiss. She sought the counsel of her trusted Gremlin, a wizard of games. Not long had passed when his disappointment became obvious. Trying to voice himself carefully, he said, 'they are like the games that your teacher would ask you to play... don't get me wrong, it's good, it's better than many other assignments'. Eryn pondered, 'do students still enjoy playing, and still see these games as "games" when it becomes an assignment, a mission with specific purposes and expectations?' Eryn grappled with her thoughts, and could not bear to keep such a discovery buried (please see Figure 8).

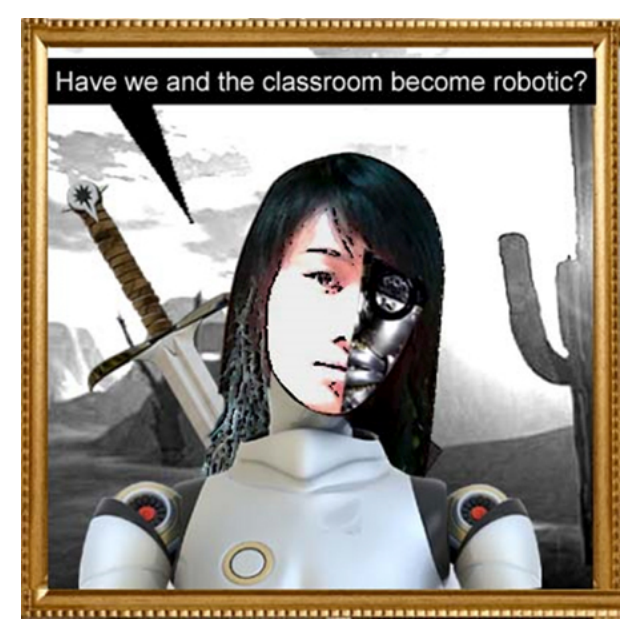


Figure 8: Eryn Neff, 'Eryn distinguishes a difference between assigned and volunteer missions', 2016. Digital image.

\section{The ordeal: Questing in the classroom}

And then it was September and the four met again in Elizabeth's cool, dimly lit cave, sheltered from the last rays of the summer sun. Becky was terrified. Unlike her fellow Quest mates, she was not teaching a class in which she could explore the very plan she felt she had forced upon her companions! But luckily, she had recruited her advisor and Mage of Museum Education, Natasha Reid, in designing an assignment for Natasha's summer course to play games on the very same sites she had set her companions on. Alas, the assignment results were more hopeless than the present state of the Quest! Becky had miscalculated students' excitement about these games, and so their work gave little insight into how, or even if, video games could help find the Sacred Knowledge. Panic and anxiety, 'the most pervasive of all psychological aspects' of being a Doctoral Student, set in (Phillips and Pugh 1994: 78).

Meanwhile, Elizabeth donned her bee suit to lead 181 undergraduates on a quest to play games (please see Figure 9). These young explorers went forth with earnestness, reporting back with Important Findings about the oversimplification of religious identity in Molleindustria's Faith Fighter game and noting a possible metaphor in a game glitch, that fighting was, in reality, unnecessary if a player made no moves to conquer other religions as 'God simply stood in a defensive pose'. And they brought back the Radical Insight that the Haring pinball game could symbolize the effect of others' identities on one's own path towards identity. 'Nice observations', she thought, 'but very content focused'. 


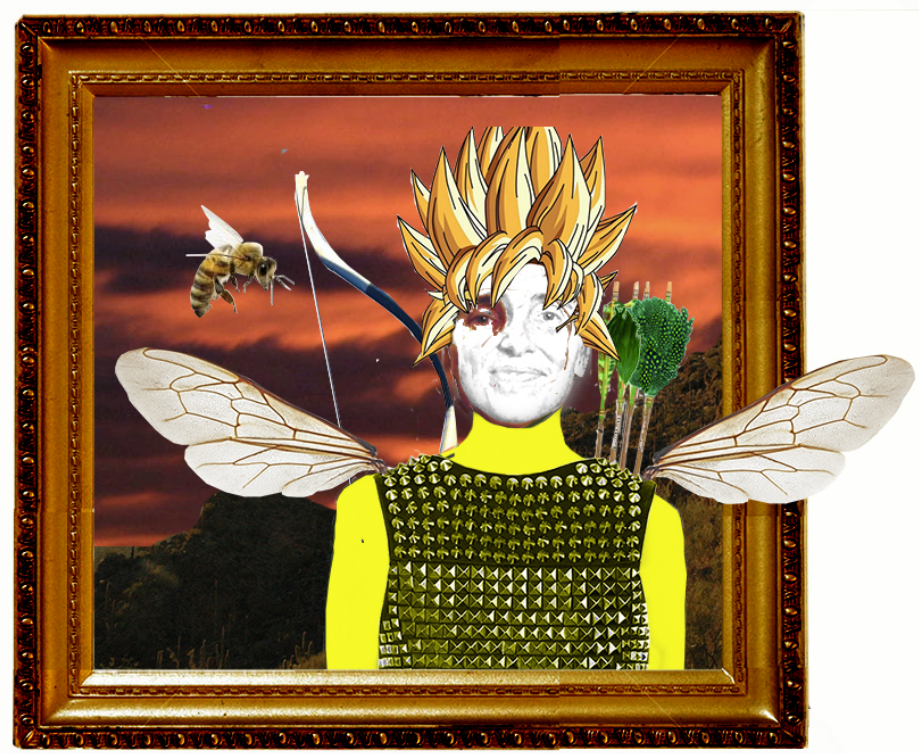

Figure 9: Elizabeth Garber, 'Elizabeth's excitement returns as a New Quest is identified', 2016. Digital image.

Manisha, Grand Pooka of a class on teaching technology and driven by a key character trait - Anxious Need to Be Useful and Productive - scouted the appeal and value of video games as artefacts and learning tools with members of her class. The young adventurers' desultory reactions, however, led her to explorations beyond the summer assignment. The students seemed to want direction, rather than play for the fun of it. 'What's the meaning of this? What's the outcome?' she posed to her companions (please see Figure 10). Intrepid companion Elizabeth pulled her out of this Pit of Anxiety with a spirited 'well, why can't play just be play? If it's play, why does it have to be academic?' 


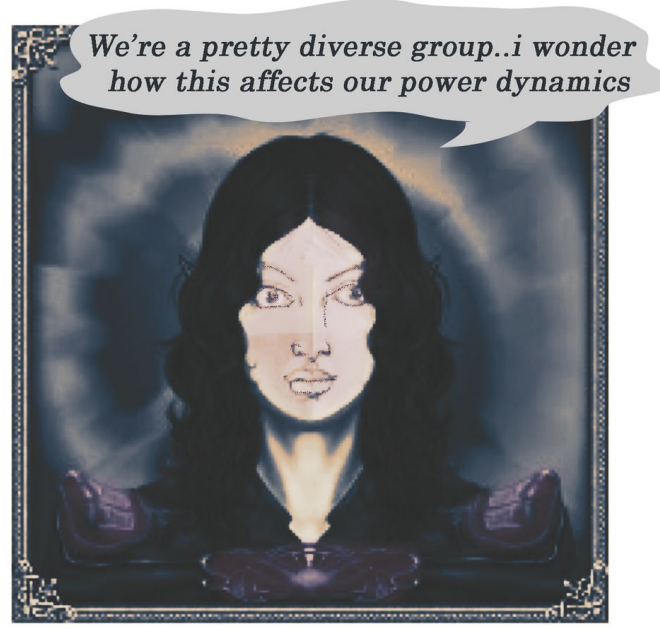

Figure 10: Manisha Sharma, 'Manisha identifies an unspoken level of the project', 2016. Digital image.

Based on her summer discoveries, Eryn designed a mission beyond a pre-designated battle, leading adventurers in her class on a journey to a utopia of informal learning (Schugurensky 2000; Greenfield 2009). The students' excitement about the challenge was like discovering an oasis in the midst of a desert. The mission was to simply play with no specific tactical objectives. Some students, entrenched in their positions, enquired how such a mission should be satisfied and in what particular time frame. 'I will let you know, but for now, just pick a game to play. If you are a gamer, you are basically doing your homework'.

On the day of the Mission Report, Eryn stood upon the concrete floor that was her stage, waiting to perform, to instruct, to provide. She did not fantasize that anything out of the ordinary would happen. And then, suddenly, as the students grouped themselves and took their turns for their Mission Report, she was not the instructor in this process (please see Figure 11).

One student began, 'I played Assassin's Creed'.

'You're with us!' came a shout from the group who had played Call of Duty. This was repeated with those who had played Zombie Catchers. 
Another student said, 'I play Candy Crush on my phone'.

'Okay, she is with that group', a student cried out as he raised his finger and pointed to a couple of students across the room while several others gestured to show their agreement.

The students were empowered by a shift in decision-making from the instructor to themselves (Wright 2011), an opportunity to be active learners (Brush and Saye 2000), and an opportunity for them to express their interests, concerns and personalities.

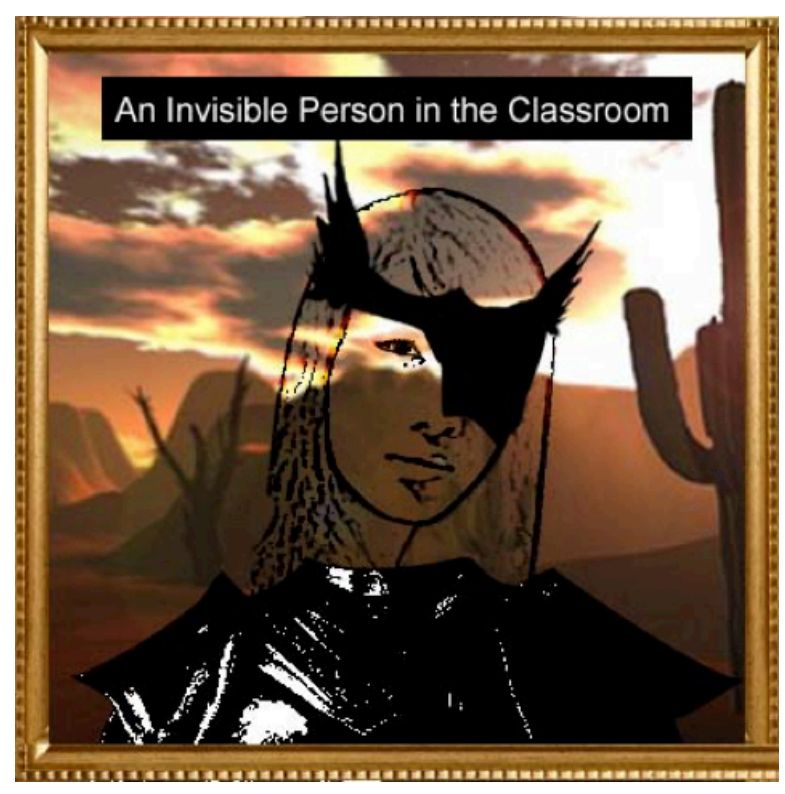

Figure 11: Eryn Neff, 'Eryn realizes she is not the instructor, her students are', 2016. Digital image.

\section{Rainbows in sight! The bridge to play}

Elizabeth secretly worried that her armour was crumbling as she began zoning out in the meeting cave. Very privately she mused, 'So much talk about gaming! Do games need to correspond to actual learning in class?' Further, she was acutely aware that indistinct Others perceived her as a separate being, due not only to years searching for Reliquaries large and small, but to her ever-hoary appearance in a land of youth (please see Figure 12). 


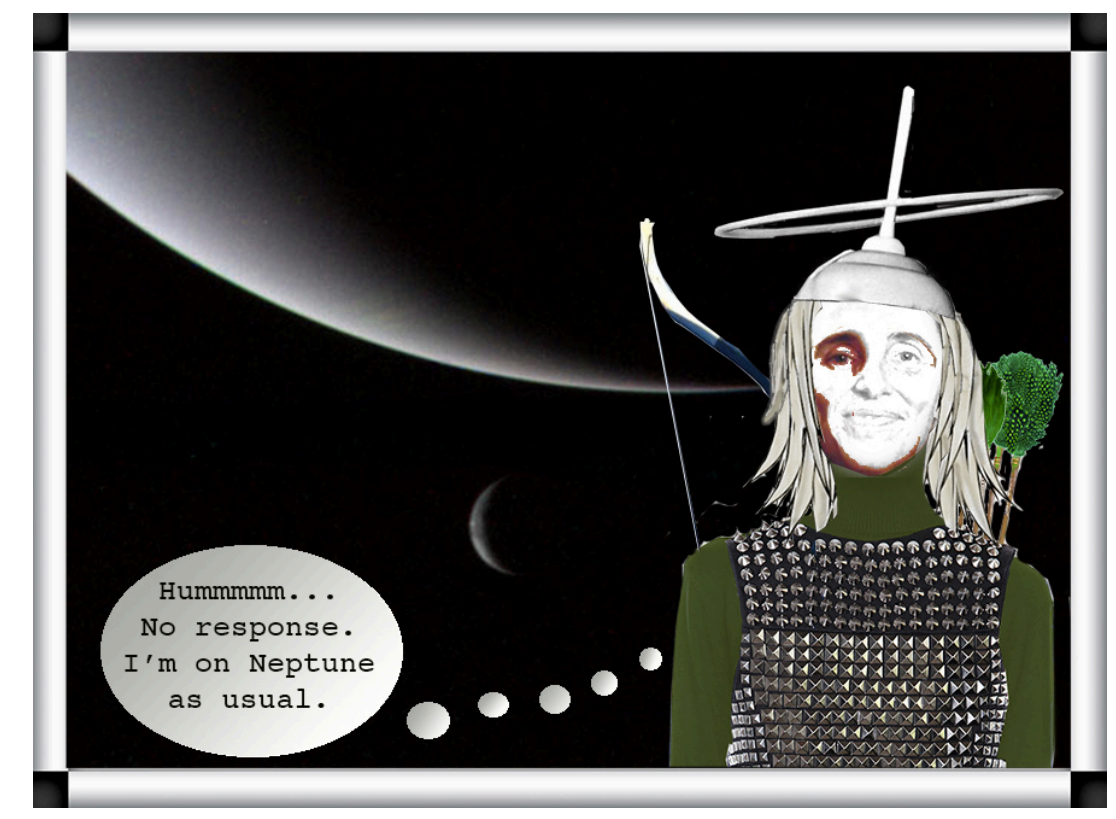

Figure 12: Elizabeth Garber, 'Elizabeth has some new misgivings', 2016. Digital image.

Clearly, something was not quite right. Or maybe everyone was on their way to the Sacred Knowledge and she was perched on Neptune? Listening to Eryn talk about her approach to having students explore games in her class and simultaneously reflecting back on learning languages, she mused that games had led her out of an apathetic state. 'We're too preoccupied with learning outcomes!' she burst out. 'Where's the fun? The open-ended and infiniteness of what we knew as children?' (Hicks 2004). Play involves learning dissociated from a primary purpose, detached from a path towards a learning goal. Play exists for its own sake (Brown 2009; Eberle 2014). And lo, she had voiced what the brave Seekers had been circling. The dust obscuring the path lifted, if just a little.

\section{Mentorship to partnership}

It was December. The Partnership, after eight months of working together, was discernable. Beginning with a discussion of video games, the companions were now talking about play in learning. This created a motivating and 'discovery rich' (Papert 1980: 162) 
environment of play-based learning (Prensky 2001). One such discovery was that in seeing her Mentors as Partners, Becky understood the gauntlet of silence in the early meetings as spaces of reflexivity and collaborative dialogue. The Faculty were creating a site for The Doctoral Students (Kantawala et al. 2009) to develop their ideas and confidence. And through group discussions of gaming experiences, their 'community of practice' (Wenger et al. 2002) also developed into a critical gaming group, 'a space - physical, social and intellectual - for faculty to interact with games and begin to understand ways that they might bring games into their courses in a more deliberate and meaningful way' (Hergenrader 2016: 35). Their group conversations were no longer awkward meetings; they were strategy sessions for the Quest!

Relieved of the need to feel intensely enthusiastic about technology per se, Elizabeth relaxed into the relationship with her hard-won Partners. She could feel an authentic part of The Partnership with or without games. And maybe feel relieved of the mantle that youth culture placed upon her as Headmistress. The Quest could be a playful pedagogy in the classroom, but also in the meetings. As Becky said, 'Talking about play has made us more excited and, well, playful' (please see Figure 13).

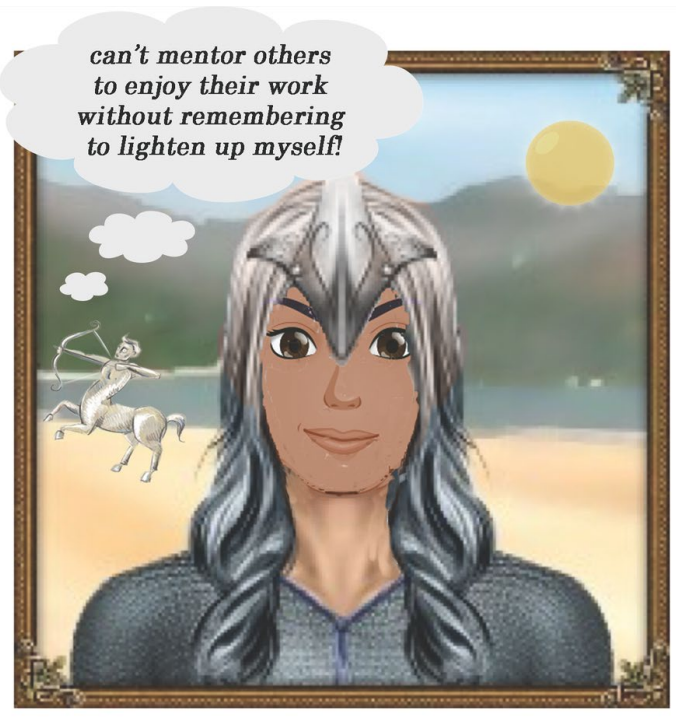


Figure 13: Manisha Sharma, 'Manisha reminds The Seekers to play', 2016. Digital image.

Manisha reflected on the moments where she felt the group had felt connected in some way. Although the anxiety to be productive and find an outcome lingered, a sense of play emerged in the spontaneity and ease that had developed in the conversations of The Seekers. Spurts of silliness, laughter and references to their home lives reflected Scholar Sages Turner and Gonzales' findings that 'mutual respect can lead to openness' (2015: 6). She felt it lent credence to their findings that peer-to-peer as well as student-faculty mentorship relationships are forged more deeply in gendered and cultural ways, in that laughter in such groups comes more naturally when all members belong to the same gender. It supported the claim that this gendered bond tends to transcend cross-cultural diversity where such openness might otherwise take years (Turner and Gonzales 2015, citing Thomas 2001; Stanley and Lincoln 2005: 6-7).

Once each Seeker understood she was part of a creative team, the imagined boundaries and identities began to fall away. Rather than the mentees receiving all the benefits of the relationship (Stokes 2003), The Faculty could as well, as reverse mentorship (Das 2012), or through 'synergistic co-mentoring' (Mullen 2000; Mullen and Lick 1999). Those spaces of reflexivity created in the meetings changed each Seeker's understanding about the malleability and potential of their roles and their relationship in The Partnership (Daloz 1983).

In those first meetings where Eryn and Becky remained only cordial recruits in this Quest, Becky mistakenly assumed Eryn would only be a colleague in the most detached sense. But through their Quest, conversation between The Doctoral Students was surprisingly easy and supportive. As is often the case in peer-mentoring relationships, the two became 'trusted friends' (Colvin and Ashman 2010: 127), with a bond forged in, at first, confusion 
and discomfort, then into a purpose-driven partnership. From each another The Doctoral Students learnt differing perspectives of the very experience in which they each were engaged, and that mentoring and partnering of one another was just as important to the Quest as was that from The Faculty.

During the search for open conversations about play, there was one constant adversary for The Doctoral Students, especially Eryn: addressing The Faculty by their first names.

'Eryn, say Elizabeth!' said Elizabeth one day as she was leaving the meeting.

'Elizabeth', Eryn repeated. It sounded so foreign. It was as though 'Elizabeth' was not even a real word!

'Did I pronounce the vowel correctly?' she reflected briefly and attempted to say it again, to get it just right, like in her pronunciation classes. She started to realize that she should challenge her traditional role as a graduate student, as a mentee (Cook-Sather et al. 2014), by using first names of The Faculty.

The dragon's egg of Sacred Knowledge was showing cracks and something dazzling had begun to radiate through, suggesting hidden pearls and buried treasures. In the gaming discussions, The Partners' dialogue began to reframe and re-examine the meanings of play: what makes a game fun? The traditional institutionally assigned roles (Glasser and Powers 2011) of advisor-student had been interrupted, shifted from someone responsible for navigating research (Baker and Griffin 2010) to a partnership with similar goals. The periodic meetings became a space to develop and infuse each Partner's creativity and enthusiasm into teaching. The idea of storytelling - personal and professional - wove through The Seekers' exploration of games, feeding and reflecting ancient traditions of leadership, communication, mentoring and philosophizing (Das 2012). Groups 'seem to encourage idea production, as for instance in systematic group procedures like brainstorming' (Cropley 2006: 129). 
Each Seeker gathered and responded to his or her Partners' ideas. Each sought the others' advice for insecurities in their classroom pursuits. Eryn sensed and immediately recognized that playing games created a dialogue. It indirectly converted and transformed the mentees' and the mentors' roles into something similar, and The Partnership was becoming real. 'Partnership brings these forms of experience and expertise into dialogue in ways that inform and support more international action' (Cook-Sather et al. 2014: 7, 8; please see Figure 14).

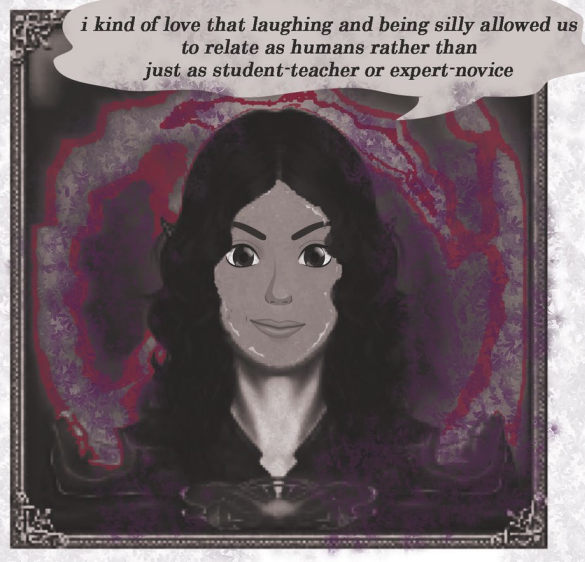

Figure 14: Manisha Sharma, 'Manisha knows The Partnership is real', 2016. Digital image.

\section{The quest for a tale: The Sacred Knowledge}

Winter had been a pleasure in the desert, but it was gone. The urgency of reporting the Mentorship Project had arrived and The Partners started to compose a story for the project. Although Eryn held a great degree of insecurity over writing in her second language, a personal story seemed bearable. Unfortunately, her fear soon returned. A new challenge, like a monster, found her in the corner, resting. This monster was fear itself: worry that she would develop into a rusty sword, unable to delight her master. Steeling her nerve, she dragged herself out of the comfortable corner, to be sharpened. What character or avatar should she 
be, she pondered. Now she was on the whetstone, her Partners performing the procedure and assisting her to become a confident being. She enjoyed her identity performances like playing games: she adopted and switched roles to accommodate whatever the space was that she was in (Omasta and Chappel 2015).

The Partners were almost confident the Sacred Knowledge would be found, or developed, in their Partnership. But then Elizabeth cried out, 'No! There is no Sacred Knowledge! We have achieved better Understanding, not Knowledge'.

'Knowledge is The Partnership,' reminded Becky. 'That was the point of the Quest'. 'But what we've found is that there is no Sacred Academic Knowledge', countered Elizabeth. 'Academic knowledge shouldn't be understood as the end of a quest. In the humanities, the point is more about deepened understanding, not any particular knowledge. This is part of what Robert Root-Bernstein (1984) meant when he argued that whereas science experiences paradigm shifts, the humanities do not. We keep building on understandings'.

'We're talking about mentorship knowledge', persisted Becky (please see Figure 15).

Manisha felt the experienced value of sharing trust, camaraderie and renewed enthusiasm for the quest was sacred in itself.

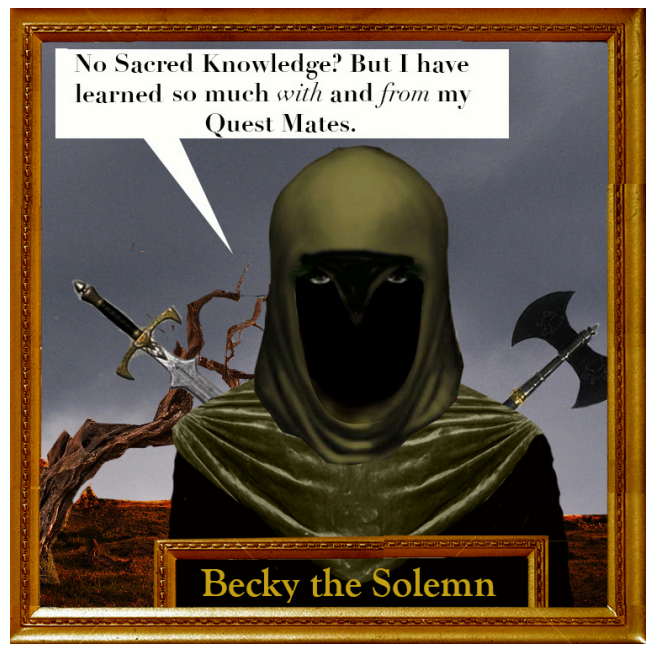

Figure 15: Rebecka Black, 'Becky considers Sacred Knowledge', 2016. Digital image. 
With doubt and astonishment, Eryn remained silent and tried to comprehend whether the journey of seeking Sacred Knowledge was just a dream, a dream of an oasis not found. This dream she was about to be awakened from, awakened and thirsty. Eryn paused and redigested the concept of 'better Understanding'. 'It is Sacred Knowledge: we started looking for Sacred Knowledge as a general idea', she posed, 'but do we have one between us?' Bovill et al. state that 'co-creation supports in students and staff the development of an enhanced meta-cognitive understanding of learning and teaching processes' (2016: 205). For Eryn, the journey of finding Sacred Knowledge was not coming to an end. It transformed into something she might have felt quite strange about in the past: a new way of sharing, absorbing and communicating between mentors and mentees.

Becky, ever sceptical, required more time to consider Elizabeth's declarations, but recognized that something else, that new way of thinking and communicating that others perceived, had indeed developed.

And so the four Partners found the door of the Academic Sages' Citadel with their Sacred Knowledge cum Understanding, leaving at its portal this Quest.

'And it was a good quest because we talked about interesting stuff', concluded Manisha.

'Did we cut enough for the 4,000 word limit?'

'I hope so,' one of The Partners mumbled as the four journeyed back to their again calescent desert kingdom. ${ }^{1}$

\section{References}

Baker, V. L. and Griffin, K. A. (2010), 'Beyond mentoring and advising: Toward understanding the role of faculty "developers" in student success', About Campus, 14:6, pp. 2-8. 
Bovill, C., Cook-Sather, A., Felten, P., Millard, L. and Moore-Cherry, N. (2016), 'Addressing potential challenges in co-creating learning and teaching: Overcoming resistance, navigating institutional norms and ensuring inclusivity in student-staff partnerships', Higher Education, 71:2, pp. 195-208.

Brown, S. (2009), Play: How it Shapes the Brain, Opens the Imagination and Invigorates the Soul, New York, NY: Avery.

Brush, T. and Saye, J. (2000), 'Implementation and evaluation of a student-centered learning unit: A case study', Educational Technology Research and Development, 48:3, pp. $79-100$.

Casto, C., Caldwell, C. and Salazar, C. F. (2005), 'Creating mentoring relationships between female faculty and students in counselor education: Guidelines for potential mentees and mentors', Journal of Counseling \& Development, 83;3, pp. 331-36.

Colvin, J. W. and Ashman, M. (2010), 'Roles, risks, and benefits of peer mentoring relationships in higher education', Mentoring \& Tutoring: Partnership in Learning, 18:2, pp. 121-34.

Cook-Sather, A., Bovill, C. and Felten, P. (2014), Engaging Students as Partners in Learning and Teaching: A Guide for Faculty, Hoboken, NJ: John Wiley. 
Cropley, A. (2006), 'Creativity: A social approach', Roeper Review, 28:3, pp. 125-30.

Daloz, L. A. (1983), 'Mentors: Teachers who make a difference', Change: The Magazine of Higher Learning, 15:6, pp. 24-27.

Das, L. (2012), 'Reflections from Indian history: Story-telling for the new age mentor', in G.

P. Prastacos, F. Wang and K. E. Soderquist (eds), Leadership through the Classics: Learning Management and Leadership from Ancient East and West Philosophy, Berlin: Springer, pp. 419-36.

Duncum, P. (2015), ‘A journey towards an art education for wired youth', Studies in Art Education, 56:4, pp. 295-306.

Eberle, S. (2014), 'The elements of play: Toward a philosophy and definition of play', American Journal of Play, 6:2, pp. 214-33.

Glasser, H. and Powers, M. (2011), 'Disrupting traditional student-faculty roles, 140 characters at a time', Teaching and Learning Together in Higher Education, Iss. 2, http://repository.brynmawr.edu/cgi/viewcontent.cgi?article=1009\&context=tlthe. Accessed 22 December 2016.

Greenfield, P. M. (2009), 'Technology and informal education: What is taught, what is learned', Science, 323:5910, pp. 69-71. 
Hergenrader, T. (2016), 'Can the professor come out and play? Establishing critical gaming group for faculty', On the Horizon, 24:1, pp. 34-37.

Hicks, L. (2004), 'Infinite and finite games: Play and visual culture', Studies in Art Education, 45:4, pp. 285-97.

Johnson, L., Adams Becker, S., Estrada, V. and Freeman, A. (2015), NMC Horizon Report: 2015 Higher Education Edition, Austin, TX: The New Media Consortium.

Jones, B. L. (2015), 'Collective learning resources: Connecting social-learning practices in deviantART to art education', Studies in Art Education, 56:4, pp. 341-54.

Kantawala, A., Hochtritt, L., Rolling, J. H., Serig, D. and Staikidis, K. (2009), 'Establishing collaborative dialogue: The mentor and the apprentice', Visual Arts Research, 35:2, pp. 40-50, http://www.jstor.org/stable/20715501. Accessed 22 December 2016.

Mullen, C. (2000), 'Constructing co-mentoring partnerships: Walkways we must travel', Theory into Practice, 39:1, pp. 4-11, http://www.jstor.org/stable/1477435. Accessed 22 December 2016.

Mullen, C., and Lick, D. W. (1999), New Directions in Mentoring: Creating a Culture of Synergy, London: Falmer Press.

Omasta, M. and Chappell, D. (eds) (2015), Play, Performance, and Identity: How Institutions Structure Ludic Spaces, New York, NY: Routledge. 
Papert, S. (1980), Mindstorms, New York, NY: Basic Books.

Phillips, E. and Pugh, D. S. (1994), How to Get a PhD: A Handbook for Students and Their Supervisors, Buckingham: Open University Press.

Prensky, M. (2001), Digital Game-Based Learning, New York, NY: McGraw-Hill.

Rockquemore, K. A. (2016), 'Why mentor matches fail', Inside Higher Ed, https://www.insidehighered.com/advice/2016/02/03/most-mentoring-today-basedoutdated-model$\underline{\text { essay?utm_content }=\text { buffer670d8\&utm_medium }=\text { social\&utm_source=facebook\&utm }}$ _campaign=IHEbuffer\#.VtJQn5zwINw.mailto. Accessed 22 December, 2016.

Root-Bernstein, R. (1984), 'On paradigms and revolutions in science and art: The challenge of interpretation', Art Journal, 44:2, pp. 109-18, http://www.jstor.org/stable/776750. Accessed 22 December, 2016.

Schugurensky, D. (2000), 'The forms of informal learning: Towards a conceptualization of the field', NALL working paper \#19-2000, Toronto, Ont.: University of Toronto, https://tspace.library.utoronto.ca/handle/1807/273. Accessed 22 December, 2016.

Stanley, C. A. and Lincoln, Y. S. (2005), 'Cross-race faculty mentoring', Change: The Magazine of Higher Learning, 37:2, pp. 44-50, http://www.jstor.org/stable/40178013. Accessed 22 December, 2016. 
Stokes, P. (2003), 'Exploring the relationship between mentoring and counselling', British Journal of Guidance \& Counselling, 31: 1, pp. 25-38.

Thomas, D. A. (2001), 'The truth about mentoring minorities', Harvard Business Review, 74:5, pp. 99-105.

Turner, C. S. V. and González, J. C. (2015), Modeling Mentoring Across Race/Ethnicity and Gender: Practices to Cultivate the Next Generation of Diverse Faculty, Sterling, VA: Stylus.

Wenger, E., McDermott, R. and Snyder, W. M. (2002), Cultivating Communities of Practice, Boston, MA: Harvard Business School Press.

Wright, G. B. (2011), 'Student-centered learning in higher education', International Journal of Teaching and Learning in Higher Education, 23:1, pp. 92-97.

\section{Contributor details}

Rebecka Black is a doctoral student in Art and Visual Culture Education at the University of Arizona, School of Art, PO 210002, Tucson AZ 85721, USA. blackr@email.arizona.edu Elizabeth Garber is Professor of Art at the University of Arizona, School of Art, PO 210002, Tucson AZ 85721, USA. egarber@email.arizona.edu Eryn Neff is a doctoral student in Art and Visual Culture Education at the University of Arizona, School of Art, PO 210002, Tucson AZ 85721, USA. erynchiu@email.arizona.edu 
Manisha Sharma is Assistant Professor of Art the University of Arizona, School of Art, PO 210002, Tucson AZ 85721, USA.msharma1@email.arizona.edu

Note

\footnotetext{
${ }^{1}$ All four Partners contributed equally to this Quest and the writing of it. They weighed, not too carefully, the listing of the names and came up with a standard alphabetical protocol.
} 